\title{
Eye color affinity to blood oxygen level
}

\begin{abstract}
The oxygen level of the blood is determined by the amount of oxygen carried by the red blood cells which are regulated continuously by our body through aerobic respiration and breathing because an appropriate maintenance of saturation of blood oxygen is essential for health. Oxygen saturation means the amount of oxygen bound to haemoglobin out of total amount of haemoglobin present in the blood. Usually there is no need to check the blood oxygen level on daily basis but people suffering from major health disorders must check it regularly because it can be helpful in estimating that either the treatments are effective or not. Eye colour is a total inherited characteristic. Mostly European infants have a very light of their iris. When child grows, melanocytes produce the pigment melanin which is responsible for the iris colour to become dark. This study was objected in order to figure out any association between colour of human eyes and their level of oxygen in blood. The blood oxygen level of all was measured with the help of a device called oximeter. A pulse oximeter helps measuring the level of oxygen in blood via infrared radiations being projected into the blood capillaries through finger, earlobe or even via toe. The reading for all was noted and analyzed further. Non- significant values of T. Test indicate no association between eye colour and blood oxygen level.
\end{abstract}

Keywords: blood oxygen level, eye color, pulse oximeter, T Test
Volume 12 Issue 2 - 2019

\author{
Muhammad Imran Qadir,Tayyaba Saher \\ Institute of Molecular Biology and Biotechnology, Bahauddin \\ Zakarriya University, Multan, Pakistan
}

Correspondence: Tayyaba Saher, Institute of Molecular Biology and Biotechnology, Bahauddin Zakarriya University, Multan, Pakistan, Email tayyabasaher1218@gmail.com

Received: February 16,2019 | Published: April 05, 2019

\section{Introduction}

The oxygen level of the blood is determined by the amount of oxygen carried by the red blood cells which are regulated continuously by our body through aerobic respiration and breathing because an appropriate maintenance of saturation of blood oxygen is essential for health. Oxygen is gathered in the lungs through metabolism of respiratory system, red blood cells and haemoglobin and is distributed throughout the body via oxygenation of blood. Oxygen saturation means the amount of oxygen bound to haemoglobin out of total amount of haemoglobin present in the blood. Oxygen demand in the body varies according to conditions like during exercise, more oxygen is needed. People living at higher altitudes have more amounts of red blood cells in their body because their body require more oxygen as compared to people living on lower altitudes. Usually there is no need to check the blood oxygen level on daily basis but people suffering from major health disorders must check it regularly because it can be helpful in estimating that either the treatments are effective or not. 95 to 100 percent is the normal blood oxygen saturation according to physicians. Below 90 percent indicates hypoxemia. Oxygen level below $80 \%$ is considered extremely lethal and it may be a sign of respiratory and cardiac illness. It can be treated by oxygen therapy which raises the oxygen in blood by oxygenation means by adding the oxygen molecules in body tissues. Mostly deoxygenating of haemoglobin occurs when partial pressure of oxygen is low in the blood. In blood gas analysis, the amount of oxygen and carbon dioxide present in blood because we breathe in oxygen and exhale carbon dioxide during respiration. An imbalance between the amounts of these gases in blood is an indication about the improper working of the lungs. In addition, this test also measures the ph. i.e. acidic or basic conditions of the blood. The test includes checking the contents of oxygen and carbon dioxide and their partial pressures along with $\mathrm{Ph}$.
It is a perception about colour of eyes that it changes with age. Eye colour is a total inherited characteristic. However, there is a little reason behind this perception. Mostly European infants have a very light of their iris. When child grows, melanocytes produce the pigment melanin which is responsible for the iris colour to become dark because melanin is continuously produced, eye colour changes. Colour of eye usually gets stable by the age of 3 to 6 months. This study was objected in order to figure out any association between colour of human eyes and their level of oxygen in blood.

\section{Material and methods}

\section{Measurement of peripheral oxygen saturation in blood}

The subjects were asked first if they are willing to be questioned for this study, then they were asked about their eye colour first and it was noted for each. The blood oxygen level of all was measured with the help of a device called oximeter. A pulse oximeter helps measuring the level of oxygen in blood via infrared radiations being projected into the blood capillaries through finger, earlobe or even via toe. The amount of radiations being reflected by the blood gases is measured. A reading on the oximeter tells about the saturation of gases of the blood. This is an easy and effective method for measuring the blood oxygen level and is preferred often. The reading for all was noted and analyzed further.

\section{Project designing}

Total participants for this study were 242 . The subjects were pupil studying at Bahauddin Zakarriya University Multan, Pakistan.

\section{Statistical analysis}

$\mathrm{M}$ stat and T. Test were performed with the use of MS excel. P value should be less than 0.05 as it is considered significant. 


\section{Results and discussion}

The linkage between colour of iris and blood oxygen level is described in the given table. With the help of this study, it was estimated that males with black eye colour have blood oxygen level with arithmetic mean of $97.63 \pm 1.89$ and females with black eye colour have oxygen level with mean of $96.78 \pm 3.03$. $96.92 \pm 2.88$ was the average oxygen level of all persons with black eye colour. No male with grey eye colour appeared in the study. $100.35 \pm 4.35$ was the arithmetic mean of blood oxygen level of all females with grey eye colour. Males with brown eye colour appeared to have the oxygen level $98.71 \pm .75$ while females with brown eye colour had oxygen saturation of $95.63 \pm 4.25$ with $95.78 \pm 4.20$ of total and p-value of 7.66 . As no p-value of the table is less than 0.05 , the results are non- significant, indicating no relation between eye colour and blood oxygen level The p- value for black and grey eye colour, when compared was 0.74 and that of grey and brown eye colour was 0.93 and that of black and brown was 0.85 , all greater than 0.05 signing about no relation between eye colour and blood oxygen level (Table 1) (Table 2).

Table I Linkage of normal blood oxygen level (mean $\pm S D)$ with eye color

\begin{tabular}{lllll}
\hline Gender & Male & female & Total & p-value \\
\hline Black eye color & $97.63 \pm 1.89$ & $96.78 \pm 3.03$ & $96.92 \pm 2.88$ & 0.12 \\
$\begin{array}{l}\text { Grey eye color } \\
\text { Brown eye }\end{array}$ & & $100.35 \pm 4.35$ & $100.35 \pm 4.35$ & \\
color & $98.71 \pm .75$ & $95.63 \pm 4.25$ & $95.78 \pm 4.20$ & 7.66 \\
\hline
\end{tabular}

Table 2 p-values for different eye colors (when compared)

\begin{tabular}{llll}
\hline Black and grey & $\begin{array}{l}\text { Grey and } \\
\text { brown eye } \\
\text { color }\end{array}$ & $\begin{array}{l}\text { Black and brown } \\
\text { eye color }\end{array}$ \\
\hline p-value & 0.74 & 0.93 & 0.85 \\
\hline
\end{tabular}

\section{Conclusion}

Non- significant values of $\mathrm{T}$. Test indicate no association between eye colour and blood oxygen level.

\section{Acknowledgments}

None.

\section{Conflicts of interest}

Author declares that there is no conflicts of interest.

\section{References}

1. Qadir MI, Malik SA. Comparison of alterations in red blood cell count and alterations in hemoglobin concentration in patients suffering from rectal carcinoma undergoing 5-fluorouracil and folic acid therapy. Pharmacologyonline. 2010;3:240-243.

2. Qadir MI, Noor A. Anemias. Rare \& Uncommon Diseases. Cambridge Scholars Publishing. England: Newcastle; 2018.

3. Qadir MI, Javid A. Awareness about Crohn's Disease in biotechnology students. Glo Adv Res J Med Medical Sci. 2018;7(3):062-064.

4. Qadir MI, Saleem A. Awareness about ischemic heart disease in university biotechnology students. Glo Adv Res J Med Medical Sci. 2018;7(3):059-061.

5. Qadir MI, Ishfaq S. Awareness about hypertension in biology students. Int J Mod Pharma Res. 2018;7(2):08-10.

6. Qadir MI, Mehwish. Awareness about psoriasis disease. Int J Mod Pharma Res. 2018;7(2):17-18.

7. Qadir MI, Shahzad R. Awareness about obesity in postgraduate students of biotechnology. Int J Mod Pharma Res. 2018;7(2):14-16.

8. Qadir MI, Rizvi M. Awareness about thalassemia in post graduate students. MOJ Lymphology \& Phlebology. 2018;2(1):14-16.

9. Qadir MI, Ghalia BA. Awareness survey about colorectal cancer in students of M. Phil Biotechnology at Bahauddin Zakariya University, Multan, Pakistan. Nov Appro in Can Study. 2018;1(3):NACS.000514.2018.

10. Qadir MI, Saba G. Awareness about intestinal cancer in university student. Nov Appro in Can Study. 2018;1(3):NACS.0005152018. 